\title{
Parlagi sas (Aquila heliaca) párok költésbiológiája a Hevesi-síkon
}

\author{
Hák Flóra ${ }^{1}$, Misik Tamás ${ }^{2, *}$ és Sasvári János ${ }^{3}$ \\ ${ }^{1}$ Magyar Madártani és Természetvédelmi Egyesület, 1121 Budapest, Költő u. 21. \\ ${ }^{2}$ Eszterházy Károly Egyetem, Környezettudományi és Tájökológiai Tanszék, \\ 3300 Eger, Leányka u. 6. \\ ${ }^{3}$ Bükki Nemzeti Park Igazgatóság, 3300 Eger, Sánc u. 6. \\ E-mail:misiktom@gmail.com
}

\begin{abstract}
Összefoglaló: A parlagi sas (Aquila heliaca) hazánk egyik legnagyobb termetű ragadozómadara, amely 1954 óta fokozottan védett. Világszerte veszélyeztetett helyzetben lévő vágómadár, amelynek egyes európai, így a hazai állományai is örvendetesen növekszenek. A parlagi sas zavarásokra érzékeny faj. Igen jelentős a fiókák mortalitási aránya is. Kutatásunk során egy őrzött parlagi sas pár megfigyelését végeztük el Füzesabony térségében, a Hevesi-sík kistájon 2014-ben. Ezen felül a Dél-Hevesi-síkon számoltuk a sikeresen fészkelő párokat, azok fiókaszámát, és elemeztük az egyes revírekben talált táplálékmaradványokat. Az örzött fészek esetében a fö célkitűzések az alábbiak voltak: (1) bemutatni az örzött fészek fiókájának gyürüzési adatlapját; (2) meghatározni a megfigyelt fészekben és a közelében talált táplálékmaradványokat; és (3) költésbiológiai szempontból vizsgálni az antropogén hatások és a madarak viselkedése közötti lehetséges összefüggéseket. A mintaterületen 2014-ben 16 pár volt sikeres; 31 fióka született az átlagosan 43 napos inkubációs idő után, és 3 fióka-pusztulás történt. A sikeres fészkeknél a kirepült fiókák száma átlagosan tehát kettő. A részletesen megfigyelt revír esetében a táplálékbőség ellenére csak egyfiókás volt a fészekalj. A vizsgált fészkeknél a madarak közül leggyakrabban erdei fülesbagolyból és varjúfélékből, az emlösök közül pedig mezei pocokból és mezei nyúlból származó táplálékmaradványokat azonosítottunk. A revírek területén gyakran zajlott mezőgazdasági tevékenység, ez azonban egyetlen pár esetében sem vezetett a fészek végleges elhagyásához. Eredményeink fontos részét képezik az éves faj-jelentésnek és a parlagi sas fajvédelmi programjának.
\end{abstract}

Kulcsszavak: fajvédelem, fokozottan védett, Vörös Lista, gyürüzés

\section{Bevezetés}

A parlagi sas (Aquila heliaca Savigny, 1809) hazánk egyik fokozottan védett ragadozómadara. A fiatal madarak sorozatos vedlés után 4-6 éves korukra érik el az adult tollazatukat, testhosszuk 72-84 centiméter, testtömegük 2450-4530 gramm (Horváth et al. 2005). A parlagi sas a biocönózis trofikus szerkezetében 
tercier konzumensnek, csúcsragadozónak számít, ezért a konzervációbiológiában zászlóshajó-fajként és kulcsfajként is kiemelt szerephez jut (Standovár \& Primack 2001). Zászlóshajó-fajként a parlagi sas veszélyeztetett, az emberiség számára kiemelt jelentőséggel bíró faj, kulcsfajként pedig fontos szerepet játszik az adott ökológiai rendszer müködésében.

A faj táplálkozását tekintve opportunista, vagyis táplálékbázisa igen változatos. A zsákmányállatok összetétele nagyon eltérhet régiónként, attól függően, hogy hol milyen táplálékforráshoz jut elsősorban a madár (Hoyo 1994). Egy 2005-ös összesített lista alapján legalább 62 faj szerepel a madarak táplálékspektrumában, azonban ebből három szerepe kiemelkedő: a mezei nyúlé (Lepus europaeus Pallas, 1778), a mezei hörcsögé (Cricetus cricetus Linnaeus, 1758), és a fácáné (Phasianus colchicus Linnaeus, 1758) (Horváth et al. 2005). Horváth és munkatársai 2010-es átfogó tanulmánya alapján pedig a parlagi sasok zsákmányának 58,9\%-át emlősök adták, míg a fennmaradó részt 46 azonosított madárfaj alkotta. A madarak közül leggyakrabban fácánt, parlagi galambot (Columba livia $f$. domestica Gmelin, 1789) és erdei fülesbaglyot (Asio otus Linnaeus, 1758) zsákmányoltak. Az emlősök osztályából kiemelkedett a mezei nyúl és a mezei hörcsög.

A faj világszerte veszélyeztetett (Meyburg 1986, BirdLife International 2008), Európában pedig ritka státuszú (BirdLife International 2004). Kontinensünkön három jelentősebb állománya ismert: az Ausztriában, Csehországban, Szlovákiában és hazánkban élő Kárpát-medencei populáció, amely jól monitorozott, és növekvő tendenciát mutat; a balkáni populáció Macedóniában, Bulgáriában és Törökországban, ahol pici, töredezett állományokat találunk; továbbá a keleteurópai Ukrajnában és Oroszországban, amely a legnagyobb, de kevéssé feltárt (Horváth et al. 2002). A parlagi sas hazai populációja a II. világháború során megfogyatkozott, és az 1980-as évek elején érte el mélypontját, amikor csupán 15-25 költőpár körül mozgott a hegyvidéki erdőkbe visszaszorult állomány (Haraszthy \& Bagyura 1993, Bagyura et al. 2002, 2003). Ekkor kezdődött el az állományadatok folyamatos rögzítése a Magyar Madártani és Természetvédelmi Egyesület Ragadozómadár-Védelmi Szakosztályának koordinálásával. A fészkelő párok száma az 1980-as évek végén növekedésnek indult, és ez gyorsuló ütemben folytatódott 2001 és 2009 között (Haraszthy 1998, Bagyura et al. 2002). Az 1991 és 2000 közötti időszakban már 388 kirepült fiókát regisztráltak. 2005-re az Európai Unió parlagisas-állománya - részben a hazai jelentős növekedés hatására - 110 párra nőtt (Demeter et al. 2005). A költőpárok száma az ezredfordulóig hazánk kivételével világszerte csökkenő vagy stagnáló tendenciát mutatott (Horváth et al. 2002, 2011). A madár európai állományának kétharmad része nálunk fészkel, így a magyarországi populáció kitüntetett hazai és nemzetközi odafigyelést érdemel. 
Hazai elterjedési területe az elmúlt három évtized során húzódott le a középhegységi erdőkből az alföldi területekre (Horváth 2014).

A parlagi sas Magyarországon 1940 óta élvez törvényes védelmet (145.900/1940 FM-rendelet), és 1954 óta fokozottan védett (59/1954 [IX. 9.] MT rendelet), mivel állománya igen sérülékeny. Szerepel a Vörös Listán; a fokozottan védett ragadozómadár pénzben kifejezett természetvédelmi értéke jelenleg 1.000.000 Ft (145.900/1940. FM-rendelet, 59/1954. [IX. 9.] MT rendelet, 13/2001. [V. 9.] KÖM-rendelet és a 100/2012. [IX. 28.] VM rendelet). 2012 és 2016 között a parlagisas-védelmi munkák jelentős része a "HELICON - A parlagi sas védelme Magyarországon" LIFE projekt keretében valósult meg.

A védelmi akciók részeként költésbiológiai megfigyelések is zajlanak, ugyanis a tojás- és a fióka-mortalitás nemcsak biotikus tényezőktől függ, hanem nagy szerepe van benne az emberi zavarásnak is. Az Európai Unióhoz való 2004-es csatlakozásunk aggodalmakat keltett az állomány jövőjére nézve, ugyanis nehéz volt megjósolni, hogy milyen következményekkel fognak járni a földhasználati változások (Demeter et al. 2005). A parlagi sas a fészek közelében történő zavarásokra nagyon érzékeny, egy autó vagy egy ember közeledése is a fészek elhagyására késztetheti a madarat (Haraszthy 1996). A költő madarak a fiókák kelésének az időszakában különösen érzékenyek, ilyenkor még a szakemberek sem mennek a fészkek közvetlen közelébe. Fejlett, 4-5 hetes korukra a fiókák már kevésbé igénylik a szülők folyamatos közelségét, ekkor már lehetőség van a gyürüzésre és a fészek alól köpetek, tollak begyüjtésére, a táplálékmaradványok helyszíni vizsgálatára (Horváth et al. 2005). A monitoring részeként minden évben június végén/július elején gyürüzés, és a befogott madarakról részletes adatgyüjtés történik, így követhetővé válik az éves fiókaszámok változása. A védelmi intézkedések részeként fészekőrzés is zajlik. A terepi jelenlét a mindennapos védelem mellett tudományos jelentőséggel is bír, mivel az ennek során begyüjtött ismeretekre alapozva biztosítható a jövőben is a faj állománynövekedése.

Kutatásunk célja a Dél-Hevesi-síkon lévő parlagi sas revírek általános monitoringja, költési sikerességük, táplálékmaradványaik helyszíni vizsgálata, valamint egy új revír őrzött fészkének részletes megfigyelése volt. Bemutatjuk az őrzött fészek fiókájának gyürüzési adatlapját és ismertetjük a helyszínen meghatározott táplálékmaradványokat. Mivel a környező területeken zajló mezőgazdasági tevékenységek egy része egybeesik a költési és az etetési időszakkal, költésbiológiai megfigyeléseink hozzájárulnak az antropogén hatások és a madarak viselkedése közötti összefüggések feltárásához is. Célunk, hogy felhívjuk a figyelmet a természetvédelem és a gazdálkodók együttmüködésének fontosságára, valamint átfogó képet nyújtsunk a parlagi sas védelmével foglalkozó szakemberek és önkéntesek munkájáról, kihangsúlyozva a fajvédelmi program aktualitását és jelentőségét. Munkánk az éves parlagi sas monitoringnak és a fajvédelmi programnak is részét képezi. 


\section{Anyag és módszer}

Vizsgálatainkat 2014 tavaszán és nyarán a Hevesi-sík kistájban végeztük (Marosi \& Somogyi 1990) (1. ábra). A 20, korábbról ismert parlagi sas revír a Dél-Hevesisíkon helyezkedett el, míg a fókuszba helyezett, Sasvári János által 2014-ben felfedezett fészek Füzesabony térségében volt található. A fészkelőhelyek pontos koordinátáit természetvédelmi okokból nem közöljük. A régió száraz éghajlattal jellemezhető. Kutatási területünk mezőgazdasági kultúrtáj részét képezi. Gyakori a kistájon a méhészkedés, ami az agrárgazdálkodás mellett ugyancsak zavarásnak minősülhet.

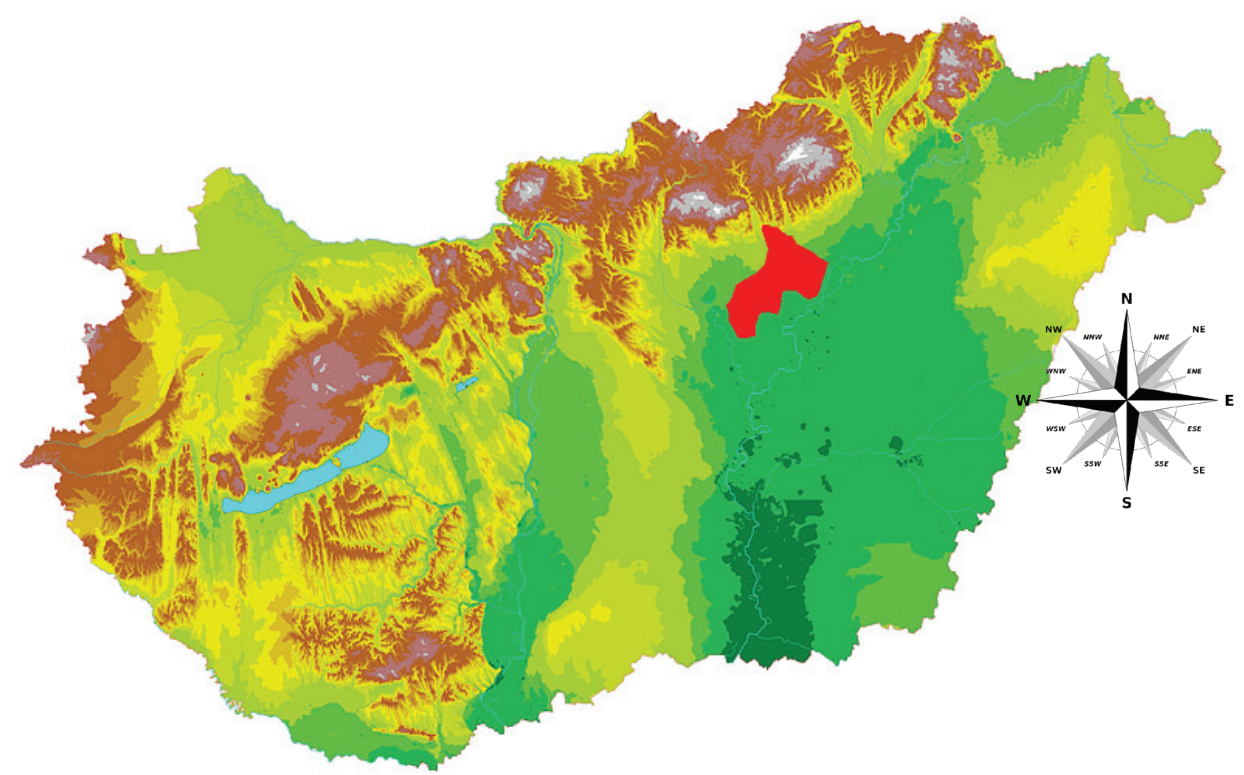

1. ábra: A Hevesi-sík elhelyezkedése Magyarországon.

A revírekben a fejlett fiókák gyürúzésére június-július hónapokban került sor. Vizsgáltuk a fészekaljak nagyságát, a táplálékmaradványokat, összegyüjtöttük a köpeteket, majd a fiókák alapadataival és a gyürüszámával együtt ezek rögzítésre kerültek. A fészekalj- és a táplálékmaradvány-vizsgálatokat a kutatási terület valamennyi revírjében elvégeztük. A táplálékvizsgálatok során a maradványokon részben helyszíni meghatározás történt, részben az összegyüjtött köpetek és maradványok elemzését később szakember végezte el. A szerteágazó munkában az MME szakembereinek vezetésével számos önkéntes vett részt.

A kiválasztott költőpár április 14-től, a kotlás kezdetétől július 29-ig, a fióka kirepüléséig állt folyamatos megfigyelés alatt, körülbelül 30 önkéntes részvételé- 
vel. A fészeknél az antropogén zavarásokkal való viselkedésbeli összefüggéseket is vizsgáltuk, a fészekőrző naplót előre megadott viselkedés- és zavarás-kódok alapján töltöttük ki.

A részletesen elemzett fészeknél a fióka gyürüzésének alkalmával (2. ábra) a madár korának becslése mellett lemértük a testtömegét, a lábtő (tarsus) hosszát, annak átmérójét, valamint a faroktoll és a hátsó karom hosszát. Ezek a kondíció ellenőrzésére is szolgálnak, hiszen az adatokból látszik, hogy egészségesen fejlődik-e a fióka. Végül rögzítettük a fészek adatait: földrajzi koordinátáit, hogy milyen fafajra épült a fészek, továbbá a fa és a fészek magasságát.

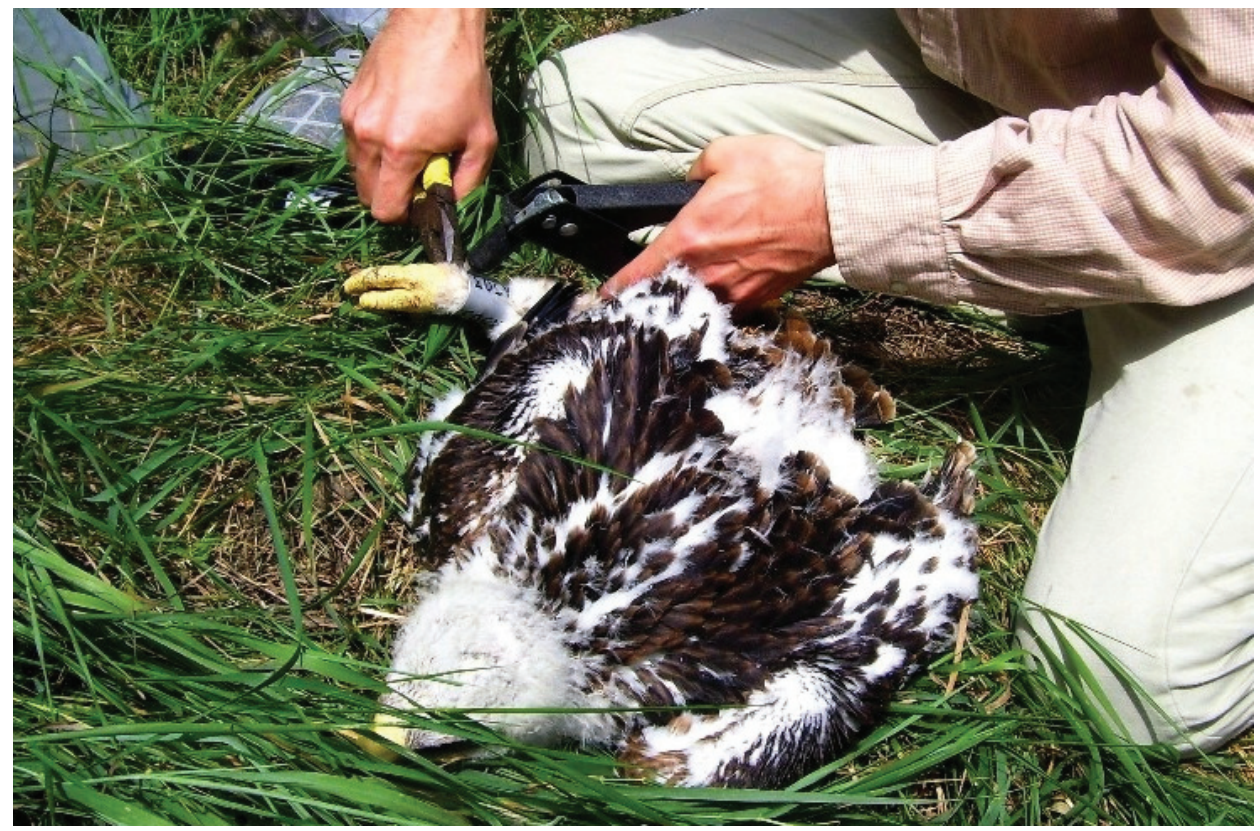

2. ábra: A megfigyelt fészekből származó parlagi sas fióka gyürüzése a Hevesi-síkon.

\section{Eredmények és értékelésük}

Költési eredmények a Hevesi-sík revirjeiben

A Dél-Hevesi-síkon 2014-ben 20 revírt jegyeztünk fel, ebböl 30 fiókát láttunk el gyürüvel. A 20 revír fészke mind az alföldi agrárterületek jellemző fáira épült: 14 darabot a madarak nemes nyárra (Populus $x$ canadensis Moench) raktak, a többit fehér akácra (Robinia pseudoacacia L.), enyves égerre (Alnus glutinosa L. Gaertn) és amerikai körisre (Fraxinus pennsylvanica Marshall) építették. Három pár költése ismeretlen okból/okokból sikertelen volt, egy pedig steril párnak bizonyult, ahol a tojás megzápult. Egy pár esetében pótköltés történt, hiszen június 
közepén nem fejlett fióka, hanem még tojás volt a fészekben. A Dél-Hevesi-síkon a 2014-es költési időszakban tehát 16 pár volt sikeres a megfigyelések időpontjában, 31 fiatal kelt ki az átlagosan 43 napos inkubációs idő után, és 3 pusztulás történt (1. táblázat), ami jó aránynak mondható (Horváth 2014). Az 1995 és 2004 között zajló kutatások szerint ugyanis a síkvidéki párok jóval alacsonyabb arányban sikeresek, mint a hegyvidéki erdőkben élők (Horváth et al. 2005). A sikeres fészkeknél a kirepült fiókák száma legtöbbször kettő, ritkább esetben egy, három fióka csak ritkán fordul elő (Horváth et al. 2005). Jelen kutatásunkban a három fiókás fészekaljak aránya $25 \%$-nak bizonyult, dominánsak a mi esetünkben is a kétfiókás fészekaljak voltak. Pelyhes kor után, mikor már a tojó nem osztja el egyenlően a fiókáknak az eleséget, a testvérekre fészken belül még jellemző lehet az élelemért való versengés, de nem olyan mértékben, mint például a békászó sas (Aquila pomarina Brehm 1831) káinizmusa.

A részletesen megfigyelt fészek esetében kirepülés után gyakran lehetett a testvéreket együtt látni; egy megfigyelésünk alkalmával azt is tapasztaltuk, hogy a két fiatal madár egymás mellett ült a földön, és csak akkor szállt fel a jobb kondícióban lévő, amikor már a személyes területüket is megközelítettük. Ez az összetartás feltételezhetően inkább túlélési stratégia jellegú, mint altruizmus, hiszen együtt sikeresebben védhetik meg magukat vagy találhatnak dögöt, esetleg zsákmányt.

1. táblázat: A fiókaszám eloszlása a Dél-Hevesi-síkon élő parlagi sas pároknál 2014-ben (n=20).

\begin{tabular}{cc}
\hline Fészekalj nagysága & Fészkek száma $(\mathrm{db})$ \\
\hline Meghiúsult költés & 3 \\
Steril pár (tojás megzápult) & 1 \\
Egyfiókás & 5 \\
Kétfiókás & 7 \\
Háromfiókás & 4 \\
Összes fióka & 31 \\
\hline
\end{tabular}

Az örzött fészek gyürüzési adatai

A Hevesi-síkon 2014-ben részletesen megfigyelt saspár fészkében csupán egy fiókát találtunk. Részletesen ennek a fiókának gyürüzési adatait mutatjuk be (2. táblázat). A madarak a fészket egy körülbelül 12 méteres fehér akácra, 10 méteres magasságba építették. A fióka átlagos fejlettsége és kondíciója a madár testsúlya $(2685 \mathrm{~g})$, valamint tarsushossza $(10,54 \mathrm{~cm})$ és a kiválasztott faroktoll hossza $(40,00 \mathrm{~cm})$ alapján átlagosnak bizonyult.

\section{A madarak viselkedése}

A részletesen megfigyelt fészek esetében mindkét költőmadár szerepe jelentős volt a kotlási időszakban. Szinte mindig a tojó ült a tojáson, a hím csupán néha 
2. táblázat: Gyürüzési adatok a Hevesi-síkon örzött parlagi sas fészeknél 2014-ben.

\begin{tabular}{cc}
\hline \multicolumn{1}{c}{ AQUHEL gyürüzés a Hevesi-síkon, 2014 } \\
\hline Revír kód & HS-28 \\
Toll / DNS & $+/+$ \\
Dátum & 2014.06 .17$. \\
Érkezés / Távozás & $10: 12$ / 11:00 \\
Fióka (élö) / Fióka (halott) & 1 / 0 \\
Gyürúszám & A503 \\
Kor (hét) / Tömeg (g) & 6 / 2685 \\
Tarsushossz (mm) / Tarsus-átmérö (cm) & 105,4 / 16 \\
Faroktoll (cm) / Hátsó karom (mm) & $40 / 30$ \\
Fafaj & 12 \\
Famagasság (m) & 10 / + \\
Fészek (m) / Köpet & fehér akác (Robinia pseudoacacia $)$ \\
\hline
\end{tabular}

vette át töle ezt a szerepet, azonban a vadászatokon kívül mindig a fészek közelében tartózkodott. Olykor berepült a fészekbe, vagy kiülőfán ült a fészektől maximum 1500 méterre. A kotlás május 16-ig tartott, eközben olykor nagyobb viharok is érintették a sasok lakóhelyét, és emberi zavarások is történtek, de ezek az események nem késztették a párt a fészek elhagyására.

Többször megfigyelhető volt a fészek zöld ágakkal való toldozása, javítása, ami jellemző a parlagi sasokra. Ennek a magyarázata a hím udvarlási viselkedése, valamint a zöld levelek párologtató szerepe, ami hőelvonással jár, ezzel is hütve a fiókát. Mindezeken túl a paraziták elleni védelmet és a fertőzés csökkentését is szolgálja a fészekben. A levelek részben takarják is a lakott fészket, valamint egyes fák levelei olyan hatóanyagokat tartalmaznak, amelyeket a paraziták elkerülnek (Haraszthy 1996).

Ahogy a fióka fejlődött, a költőpár egyre többet tartózkodott kiülőfán, és nem a fészek közvetlen közelében. Az öreg madarak felváltva hoztak zsákmányt a fészekhez, amit a fióka a pelyhes kor után már magának tépett fel. A fejlődésben lévő madár később egyre többet emelgette a szárnyait, csapkodott velük; a kirepülés előtt már sokszor ült a fészek szélén és próbálgatta az elemelkedéshez szükséges kezdő szárnymozdulatokat. Végül július 26-án hagyta el elöször hosszabb időre a fészket.

A madarak táplálkozása

A 2014-es megfigyelések idején a dél-hevesi 20 darab parlagi sas fészeknél a madarak közül leggyakrabban erdei fülesbagoly, vetési és dolmányos varjú (Corvus 
frugilegus Linnaeus, 1758 és Corvus cornix Linnaeus, 1758), továbbá fácán maradványait határoztunk meg. Az emlősök osztályából a leggyakoribb zsákmányállat ezen megfigyelések alapján a mezei nyúl és az öz (Capreolus capreolus Linnaeus, 1758) volt. Mezei nyúlra utaló maradvány szinte mindegyik revíren fellelhető volt, őzet pedig a fészkek felénél (10 revír területén) találtunk. Az általunk részletesen megfigyelt fészeknél talált táplálékmaradványok közül leggyakrabban a mezei pocok (Microtus arvalis (Pallas, 1778)) (43\%) és a mezei nyúl (17\%) került beazonosításra; a maradványok faj szerinti részletes megoszlását a 3. táblázat mutatja be.

Vizsgálataink is tükrözik, hogy a parlagi sas nem kifejezetten táplálékspecialista madár, azonban vannak meghatározó fontosságú zsákmányállatai. Az emlősök között a leggyakoribb prédának a mezei nyúl és az őz bizonyult. A mezei nyúl

3. táblázat: Meghatározott táplálékmaradványok a Hevesi-síkon őrzött parlagi sas pár revírjében 2014-ben $(\mathrm{n}=23)$.

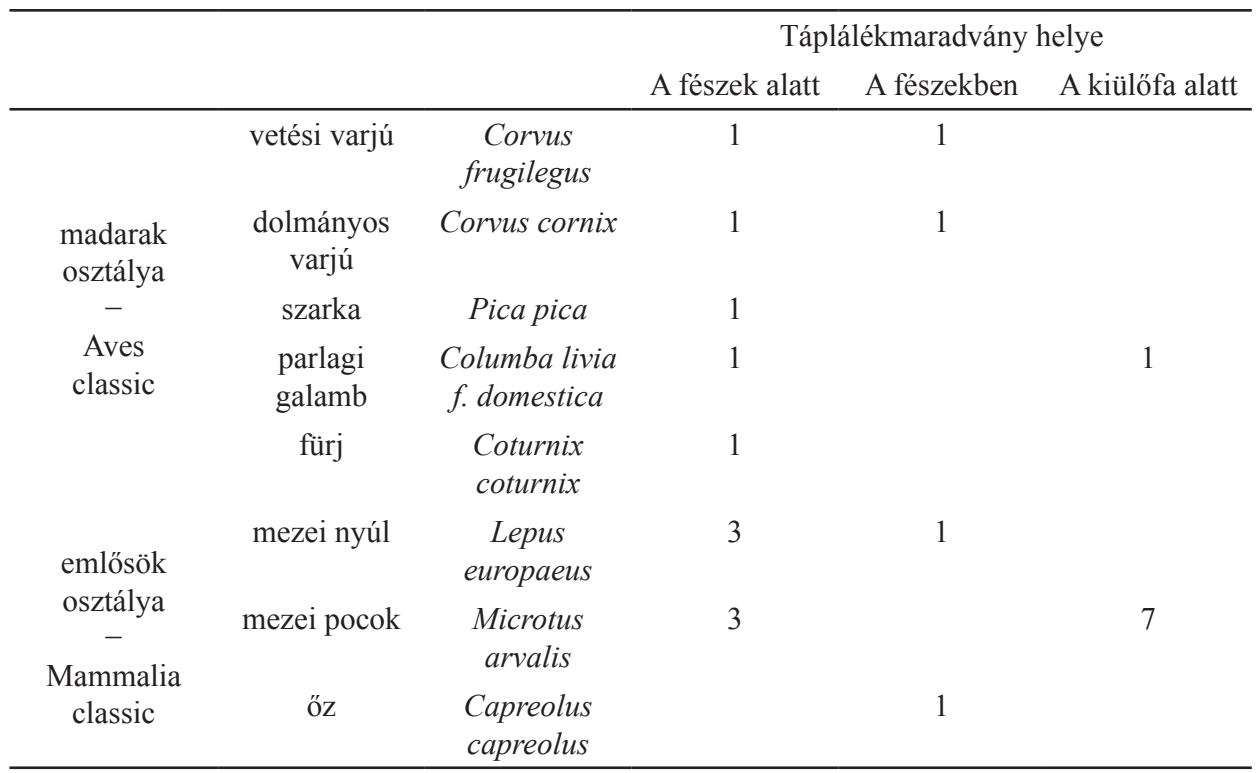

nagyon elterjedt állat a Hevesi-sík szántóföldjein, az utóbbi faj gyakorisága pedig annak köszönhető, hogy a vizsgálatok ideje egybeesett az őzgidák szezonjával és a mezőgazdasági munkákkal, amelyeknek a gidák nagy számban esnek áldozatául. Az általunk örzött sasfészekben ellenben igen magas volt a mezei pocok aránya, amely az élőhely és a vizsgálati év jelentős pocokállományával volt öszszefüggésben. 
A prédaállatok és a köpetek összetételét a kutatók az elmúlt évtizedekben alaposan feltérképezték, ennek ellenére a jövőben is fontos ezek monitorozása. Az eredményekből ugyanis következtethetünk a sasok számára táplálékbázist képező egyes fajok elterjedésére, egyedszám-dinamikájára. Mivel a parlagi sas nem táplálékspecialista ragadozó, így általa követhetővé válik a trofikus szintben alatta álló zsákmányállatok fajkészlete, indikálva, ha valamelyik faj kiszorul vagy eltünik a területről. Az 1980-as évek elején a madarak fö táplálékát a hörcsög és az ürge alkotta, nyulat csak elvétve fogtak (Schmidt \& Bécsy 1981). Az 1990es évek során vizsgált sasok által zsákmányolt 474 emlősállatból 311 ürge volt (Haraszthy et al. 1996), míg az 1995 és 2004 közötti egy évtizedet górcső alá véve a sasok prédái közül kiemelkedett a mezei nyúl, a mezei hörcsög és a fácán (Horváth et al. 2010). Horváth és munkatársai (2010) tanulmánya azt is bizonyította, hogy nem csak az idő-tényező áll a jelentős táplálék összetétel-változások mögött; a sasok táplálékbázisa aszerint is változott, hogy milyen élőhelyet foglaltak el a madarak. A változás fó oka az volt, hogy az ürge állománya országszerte megritkult, a számára alkalmas élőhelyek közül pedig számos eltűnt, illetve átalakult (Horváth 2000, Váczi 2006). Szlovákiában a kutatók 51 pár esetében gyüjtötték be 1971 és 2005 között a táplálékmaradványokat, és határozták meg ezek alapján a legfontosabb zsákmányállatokat. A leggyakoribbak az alábbiak voltak: mezei nyúl (34,6\%), mezei hörcsög (19,7\%), fácán (12,9\%) és parlagi galamb $(10,0 \%)$ (Chavko et al. 2007), vagyis a szlovák példányok zsákmányállat-összetétele nagyon hasonlít a hazai állományhoz.

\section{Zavarás}

A leggyakoribb zavarások közé a megfigyelt fészeknél a mezőgazdasági gépi munkák tartoztak, mint az aratás, vegyszerezés, és többször előfordult repülőgépes, helikopteres átrepülés, közlekedési zavarás is. A költési időszakban a tojó madár abiotikus eredetủ zavarások hatására olykor elhagyta a fészket, de rövidesen, néhány percen belül mindig visszatért rá. Arra azonban nem késztette semmi, hogy hosszabb ideig magára hagyja a tojást, vagy a fiókát.

A parlagi sas zavarásra való érzékenysége ugyan tudományosan megalapozott (Haraszthy 1993, Horváth 2000), viszont az általunk megfigyelt költőpár tagjai kevésbé ingerlékeny madaraknak bizonyultak. Jól türték a mezőgazdasági tevékenységeket, az ezzel együtt járó gyakori gépi munkák jelenlétét, zaját; kisrepülőgép, vagy helikopter átrepülése után is hamar visszatértek a fészkükre. A madarak zavarásokkal szembeni toleranciáját számos kutató vizsgálta. Horváth (2000) vizsgálatai szerint az északkeleti országrész sasfészkei jól meghatározható minimális távolságokra voltak a különböző emberi zavaró tényezőktől. A talált fészkek minimum 750 méterre voltak lakott településtől, 350 méterre müúttól, 
250 méterre vasúttól és 125 méterre elektromos távvezetéktől. Spanyolországban az ibériai sas (Aquila adalberti Brehm, 1861) fészkelőhely-választását vizsgálták, jellemezték az élőhelyet a topográfiai viszonyok, a mozaikosság, a növényborítás, az előforduló növénytársulások aránya és az emberi zavarás szempontjából is. A topográfiai tényezők kivételével az összes változó, amelyben szignifikáns különbség mutatkozott a fészkek és a random pontok között, az emberi zavarással állt kapcsolatban. Az egyes fészkek távolabb estek településektöl, müutaktól és földutaktól, továbbá a fészkek 0,5 kilométeres körzetében kevesebb elektromos távvezeték és müút húzódott (Gonzalez et al. 1992).

A fióka gyürüzése is zavarásnak számított, hiszen a fészket közvetlenül érintette, azonban az eljárás problémamentesen zajlott, és semmilyen negatív következménnyel nem járt.

\section{Gyakorlati természetvédelmi vonatkozások}

Eredményeink és az elmúlt két évtizedben a parlagi sas hazai állományában megfigyelhető pozitív tendencia azt igazolják, hogy Magyarország parlagisas-védelmi akciója és a folyamatos fészekőrzések működőképesek és hatékonyak. A faj teljes európai állományát a 2000 és 2010 közötti időszak felmérései alapján 1800-2200 párra tették, ami szignifikáns emelkedést jelentett az előző időszak vizsgálataihoz képest (Demerdzhiev et al. 2011), vagyis az ezredforduló után nem csak hazánkban, hanem a parlagi sas néhány további élőhelyén is kedvező változások történtek.

A szakembereknek továbbra is törekedniük kell az érintett gazdálkodókkal való hatékony együttmüködésre, hogy a madarak fészkelési időszakban való zavartalansága hosszú távon biztosítva legyen. Az örzés pedig nemcsak a fészek nyugalmát biztosítja, és az aktív terepi megfigyelés révén tudományos értékü adatokat szolgáltat, hanem az önkéntesek bevonásával az érdeklődők számára elérhetővé teszi a gyakorlati fajvédelmet, és növeli a társadalmi ismertségét és népszerüségét ennek a legtöbb élőhelyén veszélyeztetett fajnak. A hatékony védelem fenntartásához a már meglévő szakembereken kívül a jövő generációjának „felnevelésére” is szükség van, hiszen a parlagi sas védelme és monitoringja a jövőben is embereket és munkaerőt fog igényelni.

Köszönetnyilvánítás - A kutatás a „Parlagi sas védelme Magyarországon” címet viselő LIFE (LIFE10NAT/HU/019) projekt keretén belül valósult meg, az Európai Unió támogatásával. Köszönetet mondunk Pongrácz Ádámnak, a Bükki Nemzeti Park Igazgatóság munkatársának, aki a fészekőrző naplókat juttatta el hozzánk, Dr. Solt Bélának az öszszegyűjtött tápálálékmaradványok meghatározásáért, valamint Dr. Horváth Mártonnak, a fenti LIFE projekt vezetőjének. Hálásan köszönjük a Bírálóknak, valamint Főszerkesztő Asszonynak a javaslataikat. 


\section{Irodalomjegyzék}

Bagyura, J., Szitta, T., Haraszthy, L., Firmánszky, G., Viszló, L., Kovács, A., Demeter, Cs. I. \& Horváth, M. (2002): Population increase of Imperial Eagle (Aquila heliaca) in Hungary between 1980 and 2000. - Aquila 107-108: 133-144.

Bagyura, J., Fatér, I., Firmánszky, G., Haraszthy, L. \& Szitta, T. (2003): Parlagi sas (Aquila heliaca). - In: Haraszthy, L.(szerk.): Veszélyeztetett madarak fajvédelmi tervei. Magyar Madártani és Természetvédelmi Egyesület, Budapest, pp. 57-66.

BirdLife International (2004): Birds in Europe: population estimates, trends and conservation status. - BirdLife Conservation Series No 12. BirdLife International, Cambridge, $374 \mathrm{p}$.

BirdLife International (2008): Species factsheet: Aquila heliaca. http://www.birdlife.org

Chavko, J., Danko, Š., Obuch, J. \& Mihók, J. (2007): The food of the Imperial Eagle (Aquila heliaca) in Slovakia. - Slovak Rapt. J. 1: 1-18.

Demerdzhiev, D., Horváth, M., Kovács, A., Stoychev, S. \& Karyakin I. (2011): Status and population trend of the Eastern Imperial Eagle (Aquila heliaca) in Europe in the period 2000-2010. - Acta Zool. Bulg. 3: 5-14.

Demeter, I., Horváth, M. \& Kovács, A. (2005): Parlagisas-védelem a Kárpát-medencében 2002-2005. - A LIFE 02 NAT/H/8627 projekt összefoglaló jelentése, 15 p.

Gonzalez, L. M., Bustamente, J. \& Hiraldo, F. (1992): Nesting habitat selection by the Spanish Imperial Eagle Aquila adalberti. - Biol. Conser. 59: 45-50.

Haraszthy, L. (1993): Gyakorlati ragadozómadár-védelem. - MME Könyvtára 5., Budapest, 160 p. Haraszthy, L. (1996): Gyakorlati ragadozómadár-védelem. - Kállay György, Budapest, 160 p.

Haraszthy, L. (szerk.) (1998): Magyarország madarai. - Mezőgazda Kiadó, Budapest, 93 p.

Haraszthy, L. \& Bagyura, J. (1993): Ragadozómadár-védelem az elmúlt 100 évben Magyarországon. - Aquila 100: 105-121.

Haraszthy, L., Bagyura, J., Szitta, T. \& Petrovics, Z. (1996): Biology status and conservation of the imperial eagle in Hungary. - In: Meyburg B.-U. \& Chancellor, R. D. (eds.): Eagles studies. World working group on birds of prey (WWGBP), Berlin - London - Paris, pp. 425-428.

Horváth, M. (2000): A parlagi sas (Aquila heliaca) fészkelöhely-választása Északkelet-Magyarországon. - MSc szakdolgozat, Szent István Egyetem, Gödöllő. http://doi.org/10.13140/ RG.2.2.18719.18083

Horváth, M., Haraszthy, L., Bagyura, J. \& Kovács, A. (2002): Eastern Imperial Eagle (Aquila heliaca) populations in Europe. - Aquila 107-108: 193-204.

Horváth, M., Kovács, A. \& Demeter, I. (2005): A parlagi sas biológiája a Kárpát-medencében. - In: Kovács, A. (szerk.): Parlagisas-védelmi kezelési javaslatok. Magyar Madártani és Természetvédelmi Egyesület, Budapest, pp. 13-22.

Horváth, M., Szitta, T., Firmánszky, G., Solti, B., Kovács, A. \& Moskát, Cs. (2010): Spatial variation in prey composition and its possible effect on reproductive success in an expanding eastern imperial eagle (Aquila heliaca) population. - Acta Zool. Acad. Sci. Hung. 56: 187-200.

Horváth, M., Demeter, I., Fatér, I., Firmánszky, G., Kleszó, A., Kovács, A., Szitta, T., Tóth, I., Zalai, T. \& Bagyura, J. (2011): Population dynamics of the eastern imperial eagle (Aquila heliaca) in Hungary between 2001 and 2009. - Acta Zool. Bulg. 3: 61-70.

Horváth, M. (2014): Parlagi sas. - In: Haraszthy, L. (szerk.): Natura 2000 fajok és élöhelyek Magyarországon. Pro Vértes Közalapítvány, Csákvár, pp. 562-565.

Hoyo, J. (ed.) (1994): Handbook of the Birds of the World. Vol. 2. - Lynx Edicions, Barcelona.

Marosi, S. \& Somogyi, S. (1990): Magyarország kistájainak katasztere I. - MTA Földrajztudományi Kutató Intézet, Budapest, 479 p. 
Meyburg, B. U. (1986): Threatened and near-threatened diurnal birds of prey of the world. - Birds Prey Bull. 3: 1-12.

Schmidt, E. \& Bécsy, L. (1981): Parlagi sas. - In: Schmidt, E. \& Bécsy, L.: Ezer ágán ezer fészek. Móra Könyvkiadó, Budapest, pp. 47-50.

Standovár, T. \& Primack, R. B. (2001): A természetvédelmi biológia alapjai. - Nemzeti Tankönyvkiadó, Budapest, $542 \mathrm{p}$.

Váczi, O. (2006): The effects of abiotic environmental factors on spatio-temporal activity pattern of the European ground squirrel (Spermophilus citellus). - PhD Thesis, Eötvös Loránd University, $131 \mathrm{p}$.

Hivatkozott jogszabályok:

145.900/1940. FM rendelet

59/1954. (IX. 9.) MT rendelet a madárvédelemröl

13/2001. (V. 9.) KÖM rendelet a védett és fokozottan védett növény- és állatfajokról, a fokozottan védett barlangok köréről, valamint az Európai Közösségben természetvédelmi szempontból jelentős növény- és állatfajok közzétételéröl

100/2012. (IX. 28.) VM rendelet a védett és a fokozottan védett növény- és állatfajokról, a fokozottan védett barlangok köréről, valamint az Európai Közösségben természetvédelmi szempontból jelentős növény- és állatfajok közzétételéről szóló 13/2001. (V. 9.) KöM rendelet és a növényvédelmi tevékenységről szóló 43/2010. (IV. 23.) FVM rendelet módosításáról 


\title{
Breeding biology of imperial eagle pairs (Aquila heliaca) on the Heves-Plain
}

\author{
Flóra Hák ${ }^{1}$, Tamás Misik ${ }^{2, *} \&$ János Sasvári ${ }^{3}$ \\ ${ }^{1}$ Hungarian Ornithological and Nature Conservation Society, \\ H-1121 Budapest, Költö u. 21., Hungary \\ ${ }^{2}$ Eszterházy Károly University, Department of Environmental Sciences and Landscape \\ Ecology, H-3300 Eger, Leányka u. 6., Hungary \\ ${ }^{3}$ Bükk National Park Directorate, H-3300 Eger, Sánc u. 6., Hungary \\ E-mail:misiktom@gmail.com
}

The imperial eagle (Aquila heliaca) is one of the largest birds of prey in Hungary; it has been highly protected since 1954. The species belongs to the Accipitriformes ordo, and is classified as 'vulnerable' all over the world; but recently, their populations have been reported to show an increasing trend in Hungary and some other European countries as well. The imperial eagle is typically very sensitive to disturbances. Chick mortality rate is also remarkably high. We studied a guarded pair of imperial eagles near Füzesabony, in the Heves-Plain landscape, in 2014. In addition, the reproductive success and diet composition of the eagle pairs on the South-Heves Plain were also observed. For the guarded nets, the aims of this study were as follows: (1) to interpret the ringing data bank of the chick, (2) to determine the diet composition near and inside the nest, and (3) to investigate the possible effects of human disturbances on the birds' behaviour. On the sampling site, 16 imperial eagle pairs could breed successfully in 2014. 31 chicks hatched after an average 43 days of incubation, and 3 chicks perished. The average chick number of the successful imperial eagle pairs was 2.0 chicks per breeding pair. The particularly observed pair only hatched a single chick, in spite of the abundance of food in the area. In this area, the studied imperial eagle pairs most frequently preyed on the following: from birds, long-eared owl and crow species, from mammals, common vole and European hare. In the area of the territories, agricultural activity was frequently conducted; however, it did not lead to the final desertion of the nests, in the case of any of the eagle pairs. The results of our investigation form a part of the imperial eagle annual report, and are fundamental to the species protection program.

Keywords: species protection, highly protected, Red List, ringing 